\title{
Şehbâl Mecmuasında Yer Alan Kadınlara Ait Giysi Önerileri
}

\section{Women's Clothing Recommendations in the Şehbâl Magazine}

\section{Kenan Saatçioğlu}

Dr. Öğr. Üyesi, Süleyman Demirel Üniversitesi, Güzel Sanatlar Fakültesi, Tekstil ve Moda Tasarımı Bölümü email: saatciogluk@gmail.com (DORCID ID: https://orcid.org/0000-0002-1026-1090

\author{
$\checkmark$ iThenticate" $\mathrm{Bu}$ makale bilimsel etik ve kurallara uygun hazırlanmış ve intihal incelemesinden geçirilmiştir. Etik kurul onayı \\ gerektirmemektedir.
}

\section{Atıf (APA 6)/To cite this article}

Saatçioğlu, K. (2020). Şehbâl mecmuasında yer alan kadınlara ait giysi önerileri. Atatürk Üniversitesi Güzel Sanatlar Enstitüsü Dergisi, 26(45), 511-520. doi: https://doi.org/10.35247/ataunigsed.733422

Makale Gönderim Tarihi/Received: 06/05/2020

Makale Kabul Tarihi/Accepted: 20/09/2020

Makale Yayın Tarihi/Published: 22/10/2020

Review Article/Derleme Makalesi

\section{Öz}

Șehbâl Mecmuası, sosyal hayatın büyük oranda değişime uğradığ1 ve birçok alanda yenilik hareketlerinin görüldüğü Osmanlı İmparatorluğu'nun son döneminde büyük ilgi uyandırmış önemli bir yayın organı olarak karşımıza çıkmaktadır. Özellikle kadınlar ile ilgili konulara oldukça geniş yer ayıran mecmuanın birçok sayısında, dönemin giysi modası hakkında bilgi veren kadınlara ait giysi önerilerinin yer aldığ 1 içeriklere sıklıkla rastlanılmıştır. Bu içeriklerde dönemin Batı modasını yansıtan giysi örnekleri yer almıș ve özellikle eğitimli olarak nitelendirilebilecek monden Müslüman Türk kadınları, mecmuanın mevcut içeriklerini takip ederek dönemin Batı tarzını yansıtan giysi modası hakkında bilgi sahibi olmuşlardır. Mevcut çalışmada, II. Meşrutiyet Dönemi sonrası yayımlanmış olan Şehbâl Mecmuası'nda giysi modası hakkındaki içeriklerde yer alan kadınlara ait giysi önerilerinin tespit edilmesi amaçlanmıştır. $\mathrm{Bu}$ amaç doğrultusunda, Bonn Üniversitesi Kütüphanesi'nde bulunan mecmuanın 1914 (1330) yılında Osmanlıca olarak yayımlanmış sayılarında, kadınlara ait giysi önerilerinin bulunduğu içerikler belirlenmiş ve belirlenen bu içeriklerde yer alan kadın giysi önerileri yorumlanarak ortaya konulmuştur. Ortaya konulan bu içerikler incelendiğinde, mevcut dönemdeki kadınların dönemin Batı modasını yansıtan giyimkuşam özellerini takip ettikleri sonucuna ulașılmıştır.

Anahtar kelimeler: Şehbâl Mecmuası, Giysi Modası, Kadınlara Ait Giysi Önerileri

\begin{abstract}
Sehbâl Magazine is an important publication which has aroused interest in the last period of the Ottoman Empire, where social life changed greatly and reformist movements was seen in many areas. The magazine gave wide range of issues related to women, especially in many editions of the magazine, the contents that gave information about the fashion of the period were frequently found in the content of women's clothing recommendations. These contents included examples of clothing reflecting the Western fashion of the period. Especially, Turkish Muslim women who can be described as well educated, followed the current contents of the magazine and were informed about the Western fashion of the period. The aim of this study is to determine women's clothing recommendations in the contents related to fashion in Sehbâl Magazine published after the Second Constitutional Era. In line with the stated purpose, the contents published in the Ottoman language in 1914 (1330), containing the recommendations of women's clothing were determined in the University of Bonn Library. Additionally, recommendations of women's clothing in these contents were interpreted. When these contents were examined, it was concluded that the women in the current period followed the dress codes reflecting the Western fashion of the period.
\end{abstract}

Keywords: Şehbâl Magazine, Fashion, Women's Clothing Recommendations

\section{Giriş}

1908 yılında gerçekleşen II. Meşrutiyet'in ilanı ile birlikte Osmanlı İmparatorluğu'nda yaşayan kadınlar sosyal, siyasal, düşünsel ve ekonomik alanlar içerisinde ortaya çıkan yenilik hareketleri doğrultusunda kendilerini yeni bir hayatın içerisinde bulmuşlardır. Mevcut dönemdeki yenilik hareketleri ile birlikte Osmanlı toplumunda beliren bu yeni hayat anlayışı içerisinde kadınlar edebiyat, sanat, müzik vb. sosyal alanlarda olduğu gibi moda alanında da giyim-kuşam tercihleri ile önceki dönemlere kıyasla farklı bir tarzın ortaya çıkmasını sağlamışlardır. Özellikle imparatorluğun çok uluslu kentleri olarak nitelendirilebilecek İstanbul, İzmir, Selanik ve Beyrut gibi kentlerde yaşayan kent yaşamının birer temsilcisi konumundaki Müslüman Türk kadınları, dönemin Batı modasına ait giyim-kuşam tarzlarını yakından takip etme firsatını yakalamışlardır. Dönemin kent yaşamında yer alan bu kadınlar takip ettikleri Batı tarzlı giyim-kuşam özelliklerini geleneksel yapıdaki giysileri ile bütünleştirerek, II. Meșrutiyet Dönemi sonrasında Osmanlı İmparatorluğu içerisinde ortaya çıkan bu yeni giyim-kuşam tarzını günlük yaşamlarında sıklıkla yansıtmışlardır.

II. Meşrutiyet'in ilanıyla sosyal alanlarda kendilerine sunulan imkânların gelişmesi ile birlikte toplum içerisinde önemli bir konum elde eden Müslüman Türk kadınları, daha bilinçli bir bakış açısıyla giyim-kuşam tercihlerini şekillendirmişlerdir (Çakır, 2011, s. 249). Özellikle 18. yüzyıldan itibaren Batı tarzının Osmanlı İmparatorluğu üzerinde var olan etkisinin II. Meşrutiyet Dönemi'nde de artarak devam etmesi, kadınların dış görünümlerini doğrudan etkilemiş ve kadınların dönemin Batı modasının izlerini taşıyan bir giyim-kuşam anlayışını benimsemesine olanak sağlamıştır (Toprak, 2017, s. 231-232). Batı ile Doğu toplumları arasındaki sosyal yaşam farklılıklarına rağmen kamusal alanda yer alma arzusu içinde bulunan kent yaşamının temsilcisi olan Osmanlı İmparatorluğu'ndaki kadınlar, bu dönemde yükselişe geçen seküler düşünce yapısı doğrultusunda moda olgusunu 
ön plana taşıyarak yeni süslenme biçimlerini ortaya çıkarmışlardır (Özer, 2009, s. 47; Şahin, 2015, s. 27). Böylece geleneksel Osmanlı giyim-kuşamının önemli göstergeleri olan çarşaf, ferace, maşlah, yeldirme gibi giysi parçalarını, dönemin Batı modasına ait bluz, manto, pelerin, veston gibi toplum için yeni olan giysi parçaları ile birleştiren kadınlar, ortaya koydukları bu tarz doğrultusunda yeni hayatın içerisinde var olmaya başlamışlardır. Bir nevi öncelikle Osmanlı saraylarında görülen Batı tarzlı giysi modasına ait unsurlar 19. yüzyılın sonlarına doğru kentli kadınlar arasında hızla yayılmaya başlamıştır (Yılmaz, 2020, s. 38).

Mevcut dönemde Müslüman Türk kadınların giyim-kuşam tercihlerinin oluşmasında dönemin gelişen basın organlarının önemli bir etkisi olduğu görülmektedir. Bu dönemde, özgürlükçü düşünce anlayışı doğrultusunda kadınlara yönelik olarak ortaya çıkan bir süreli yayın olan mecmuaların sayısında ciddi bir artış gözlemlenmiştir. Döneme ait bu mecmualar, kadınların sosyal hayata etkin bir şekilde katılımını destekleyerek, kadınların sesi olma iddialarına rağmen bilhassa üst sınıf Müslüman Türk kadınlara hitap etmişlerdir (Denman, 2009, s. 43). Özellikle kent yaşamının birer parçası olan, okuma ve yazma bilen, en az bir yabancı dile sahip monden (Fransızca kökenli "mondain" sözcüğünden dilimize geçmiş olan bu sözcük, dilimizde "yüksek sosyete yaşamını seven" anlamını karşılamaktadır) (Monden, t.y.) olarak nitelendirilen yeni yaşam anlayışııın ortaya çıkardığı mevcut kadın kimliğine yönelik olan mecmuaların tefrikalarında (Arapça kökenli "tefrika" sözcüğünden dilimize geçmiş olan bu sözcük, dilimizde "gazete veya mecmualarda çıkan, birbirini tamamlayan yazılardan oluşan dizi" anlamını karşılamaktadır) (Tefrika, t.y.), sosyal konulara ait dönemin Batı anlayışını temsil eden içeriklere sıklıkla rastlanılmıştır (Barbarosoğlu, 2012, s. 143-144). Sosyal yaşama ilişkin birçok konunun ele alındığı bu süreli yayınlardaki haber, fotoğraf, makale vb. içerikler, kentli Müslüman Türk kadınların oldukça ilgisini çekmeyi başarmıştır (Demirdirek, 2011, s. 10).

Bu içerikler ele alındığında, yeni yaşam anlayışı içerisinde yer alan kadınlara yönelik giyim-kuşam, aksesuar, saç ve makyaj gibi konuların mevcut mecmualar tarafından sıklıkla vurgulandığı ortaya çıkmaktadır. Mecmualarda dönemin moda anlayışı hakkında bilgilerin verildiği ve böylece Müslüman Türk kadınların mevcut dönemin giyim-kuşam tarzlarını şekillendiren ve dünyada öncü olan Paris modasını daha yakından tanıma firsatı elde ettikleri ile karşılaşılmışıı (Demir, 2016, s. 73). Çeşitli biçki-dikiş teknikleri, moda terimleri, giysi kalıpları gibi içeriklere sayılarında geniş yer ayıran bu mecmualarda, kadınların en önem verdiği içeriklerden birisinin de döneme ait giysi önerilerinin olduğu görülmektedir. Dönemin Batı tarzlı giyim-kuşam anlayışını yansıtan mecmualar içerisindeki mevcut giysi önerileri ile kadınlar, dönemin moda anlayışının farkına varmışlar ve böylece beğendikleri giysi modellerini biçki-dikiş bilen kadınlar kendileri dikerek, bilmeyenler ise dönemin terzilerine diktirerek bu giysilere sahip olma şansını elde etmişlerdir. Böylece Osmanlı İmparatorluğu içerisinde yaşayan kentli Müslüman Türk kadınları, dönemin Batı tarzlı giyim-kuşam modasını yakından takip ettiklerini birbirlerine kanıtlama yarışı içerisine girmişlerdir.

Kadınlara ait giysi önerilerinin yer aldığı dönem mecmuaları ele alındığında bu mecmular arasında 1909-1914 (1325-1330) yılları arasında çıkarttı̆̆ toplam yüz sayıyla okuyucu kitlesi ile buluşmuş olan Şehbâl Mecmuası'nın ön plana çıktığı görülmektedir. Dönemin diğer mecmuları ile kıyaslandığında, Şehbâl Mecmuası'nın önemli bir yazar kadrosuna sahip olması, mecmua içerisinde çok sayıda fotoğrafa ve illüstrasyona yer verilmesi ve o döneme kadar çok az kullanılan kuşe kâğıdın mecmuanın basımında kullanılmasıyla yüksek bir baskı kalitesinin yakalanması gibi etkenler mecmuayı oldukça önemli bir konuma taşımış̧ır (Kocabaşoğlu, 2010, s. 61). Yoğun bir kadın okuyucu kitlesine ulaşan mecmuada yer alan kadınlara ait giysi önerilerinin genellikle "Moda" başlıklı köşelerde yayımlandığı ortaya çıkmaktadır. Mecmuanın bu bölümlerinde yayımlanmış yazı içeriklerinin büyük çoğunluğunun kadın yazarlar tarafindan ele alındığı bilinmektedir. Ayşe Bedia, Prenses Kadriye Hüseyin, Salime Servet Seyfi, Fatma Âliye, Halide Salih gibi kadın yazarların yanı sıra az sayıda da olsa İzzet Melih Devrim, Bedii Nuri gibi erkek yazarların da döneme ait moda kavramı ile ilişkili yazıların yer aldığı içerikleri kadın okuyucular ile buluştuklarına rastlanılmaktadır (Ahmetoğlu, 2010, s. 74-75).

Mevcut çalışmada, II. Meşrutiyet Dönemi'nin en önemli mecmualarından birisi olan Şehbâl Mecmuası'nın giysi modası hakkındaki içeriklerinde yer alan kadınlara ait giysi önerilerinin tespit edilip, gün ışığına çıkarılması amaçlanmıştır. Ortaya konulan amaç doğrultusunda, mecmuanın 1914 (1330) yılında Osmanlıca olarak yayımlanmış sayılarında kadınlara ait giysi önerilerinin bulunduğu bu içerikler tespit edilmiş ve belirlenen içeriklerde yer alan kadın giysi önerileri tercüme edilmiş ve yorumlanarak gün ışığına çıkarılmıştır. Bu doğrultuda 1914 (1330) yılı Mart, Nisan, Mayıs Haziran ve Temmuz aylarında yayımlanmış olan sekiz farklı sayıda bulunan kadınlara ait giysi önerileri, betimsel araştırma yöntemlerinden tarama yöntemi doğrultusunda tespit edilip ele alınmıştır. Mevcut içeriklerin tespit edildiği mecmualarda yer alan kadınlara ait giysi önerileri başlıklarıyla birlikte çalışma içerisinde kronolojik olarak sınıflandırılıp açıklanmıştır. Ortaya konulan bu çalışmanın mevcut dönemde Osmanlı İmparatorluğu'na ait önemli bir süreli yayın olan Şehbâl Mecmuası hakkında bilgiler vermesi, bununla birlikte bu mecmuada yer alan dönemin giysi modası hakkında çıkarım yapılabilecek içerikleri yansıtması açısından önem taşıdığ düşünülmektedir. Bu amaç ve önem doğrultusunda, Bonn Üniversitesi Kütüphanesi'nde bulunan mecmuanın 1914 (1330) yılında Osmanlıca olarak yayımlanmış sayılarında, kadınlara ait giysi 
önerilerinin bulunduğu bu içeriklerde yer alan kadın giysi önerileri yorumlanarak bu çalışma içerisinde yansitılmıştır.

\section{Yöntem}

Araştırma "Betimsel Model"e dayalı nitel bir araştırmadır. Bu kapsamda, II. Meşrutiyet Dönemi sonrası yayımlanmış olan Şehbâl Mecmuası'nda giysi modası hakkındaki içeriklerde yer alan kadınlara ait giysi önerilerinin tespit edilmesi amaçlanmıştır. Bu amaç doğrultusunda, Bonn Üniversitesi Kütüphanesi’nde bulunan mecmuanın 1914 (1330) yılında Osmanlıca olarak yayımlanmış sayılarında, kadınlara ait giysi önerilerinin bulunduğu içerikler belirlenmiş ve belirlenen bu içeriklerde yer alan kadın giysi önerileri yorumlanarak ortaya konulmuştur.

\section{3. Şehbâl Mecmuası}

Şehbâl Mecmuası, Osmanlı İmparatorluğu'nda yenilik hareketlerinin önemli bir noktası olarak nitelendirilebilecek II. Meşrutiyet Dönemi sonrası, 1909-1914 (1325-1330) yılları arasında yaklaşık beş yıllık bir süre içerisinde, toplamda yüz sayı ile yayımlanmış bir basılı yayın olarak karşımıza çıkmaktadır. Mecmuanın neden böyle bir adı tercih ettiği bilinmemekle birlikte, Farsça kökenli "şahbal" sözcüğünden dilimize geçmiş olan Şehbâl kelime anlamı olarak "kuşkanadının en uzun tüyü, şehper" olarak açıklanmaktadır (Develioğlu ve Kılıçkını, 1975). On beş günde bir okuyucu kitlesi ile buluşmuş dönemin bu kültür ve aktüalite mecmuası, 1 Mart 1909 (1 Mart 1325) tarihinde yayın hayatına başlamış ve 15 Temmuz 1914 (15 Temmuz 1330) tarihinde yayın hayatını sonlandırmış̧ır. Dönemin önemli bir siyasal yapılanması olan İttihat ve Terâkki Cemiyeti’ne yakın aydın kişilerinden hukukçu ve besteci Hüseyin Sadeddin Arel tarafindan kurulan mecmua, Osmanlı İmparatorluğu'nun başkenti olan İstanbul'da dönemin Yeni Postane (günümüzde "Büyük Postane" olarak bilinen İstanbul'un Fatih ilçesine bağlı Sirkeci semtinde bulunan, 1909 yılında çalışmaya başlayan Osmanlı İmparatorluğu'nun ve Türkiye Cumhuriyeti'nin en büyük postanesidir) karşısındaki Ferouh Bey Han (dönemin Art Nouveau tarzında inşa edilmiş ve günümüzde "Vlora Han" olarak adlandırılan bu mekân mevcut dönemde "Ferouh Bey Han" olarak adlandırılmaktaydı) 9, 10 ve 11 numaralı adreste yayınlarının içeriklerini oluşturmuştur (Uymaz, B., 2005, s. 15). Mecmuanın idari müdürlüğünü ise sırasıyla Ali Rıza Seyfi, Jak Sayabalyan ve Necati Bey yürütmüștür (Kocabaşoğlu, 2010, s. 61).

Kapak sayfasından da yer alan "On beş günde bir neşrolunur ve her şeyden bahseder risale-i musavvere" (Risale: Arapça kökenli "risale" sözcügünden dilimize geçmiş olan bu sözcük, dilimizde "küçük kitap, broşür" anlamını karşılamaktadır (Risale, t.y.), Musavver: Arapça kökenli "muşavver" sözcügünden dilimize geçmiş olan bu sözcük, dilimizde "resim konulmuş, resimli" anlamını karşılamaktadır (Musavver, t.y.)) cümlesinden de anlaşılacağı gibi Şehbâl Mecmuası'nın on beş günde bir yayımlanmasının yanı sıra siyaset, edebiyat, kültür ve magazin gibi döneme ilişkin birçok konudan sıklıkla bahsettiği karşımıza çıkmaktadır. Bunun yanı sıra mecmuanın matrislerinin (Fransızca kökenli "matrice" sözcüğünden dilimize geçmiş olan bu sözcük, dilimizde "baskı yoluyla teksir için kullanılan, girintili çıkıntılı metal veya mukavva kalıp, baskı kalıbı" anlamını karşılamaktadır (Matris, t.y.)) İtalya'da hazırlandığı bilinmektedir (Uymaz, T., 2005, s. 15). Mecmuanın basım süreçleri Osmanlığı İmparatorluğu'nda bulunan Agop Matyosyan Matbaası, Şant Matbaası, Matbaa-i Hayriye ve Ortakları Matbaası ve Karabet Matbaası gibi birbirinden farklı matbaalarda basılmıştır. Dönemin diğer mecmuaları ile kıyaslandığında Şehbâl Mecmuası'nın baskı kalitesi ve sayfa düzeni gibi fiziki şartların yanı sıra zengin içeriği ve yazar kadrosu gibi açılardan da ön plana çıktı̆̆ görülmektedir. Mevcut dönemde büyük bir okuyucu kitlesinin tercih ettiği mecmuanın Osmanlı İmparatorluğu topraklarında 5 kuruştan satıldığı bilinmektedir. Bunun yanında mecmuanın okuyuculara abonelik hizmeti de sağladığı, altı aylık aboneliğin yarım Osmanlı lirası, bir yıllık aboneliğin ise bir Osmanlı lirası olduğu görülmektedir. Mecmuanın yurtdışında bulunan okuyuculara da İngiliz ve Fransız para birimlerinde satışının gerçekleştiği karşımıza çıkmaktadır. (Ahmetoğlu, 2010, s. 30-32).

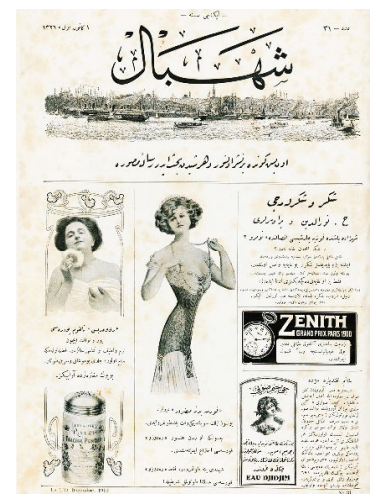

Resim 1. Şehbâl mecmuası kapak sayfasından bir örnek 
Şehbâl Mecmuası'nın içeriği incelendiğinde ise, mecmuanın döneme ait teknoloji, doğa olayları, edebiyat, felsefe, siyaset, güzel sanatlar ve müzik gibi konularla ilgili yazılara oldukça geniş yer ayırdığı ortaya çıkmaktadır. Mevcut dönemde kadın okuyucusu kitlesine ulaşmayı hedefleyen bu mecmua içerisinde, kadın okurlara yönelik olarak hazırlanmış kadın hakları, kadınların toplum içerisindeki yerleri, ebeveynlik, makyaj ve moda gibi konular yazarlar tarafından oldukça gündeme getirilmiştir. Bununla birlikte, mecmua içerisinde "Moda" başlığı altında kadınlara ait giysi önerileri, biçki-dikiş talimatları, giysi, kumaş, aksesuar vb. konularla ilişkili reklam örnekleri gibi özellikle kadın okuyucuları ilgilendiren içerikler çeşitli fotoğraf, illüstrasyon ve yazı karakterleri ile okuyuculara sunulmuştur (Ahmetoğlu, 2010, s. 13).

\subsection{Kadınlara Ait Giysi Önerileri}

II. Meşrutiyet Dönemi ile birlikte Osmanlı İmparatorluğu içerisinde yoğun bir şekilde hissedilen Batılılaşma hareketleri, özellikle giyim-kuşam, aksesuar, saç ve makyaj gibi konuları kapsayan moda kavramını oldukça etkilemiştir. Bu dönemde dünyada öncü olan Paris modası Osmanlı kadınlarının oldukça ilgisini çekmiş, özellikle kentli kadınlar bu modaya ilişkin tarzları kendi giysilerine uyarlamışlardır (Himam ve Tekcan, 2014, s. 238). Belirtilen dönemde moda kavramı, dönemin gazete ve mecmualarında sıklıkla yer almış, böylece dönemin kentli kadınları arasında gündem oluşturarak daha da ilgi çekici hale gelmeye başlamıştır. Özellikle dönemin Şehbâl, Hayal, Kadın, Süs, Sevimli Ay, Resimli Ay vb. kadın okuyucu grubuna hitap eden mecmualarda yazarlar tarafından gündeme taşınan moda konusu hakkında, olumlu ya da olumsuz birçok görüşün yer aldığı içeriklere rastlanılmıştır (Özer, 2009, s. 365).

Bu içerikler ele alındığında, özellikle mecmualarda dönemin giyim-kuşam tarzlarını şekillendiren Paris modasına ait giysi modellerinin kadınlara tanıtıldığı görülmektedir. Sayıları giderek artan kadın mecmularında moda haberleri, yeni giysi modelleri ve bu giysilerin nasıl dikileceklerine dair teknik bilgiler neredeyse tüm kadın mecmualarındaki içeriklerde rastlanılmıştır (Demir, 2018, s. 60). Dönemin Batı tarzlı giyim-kuşam anlayışının Osmanlı İmparatorluğu içerisinde yaşayan Müslüman Türk kadınlarına tanıtıldığı bu içerikler, çoğunlukla yazarlar tarafindan dönemin uluslararası dili olan Fransızcadan tercüme edilerek bu mecmualardaki yerlerini almışlardır. Şehbâl Mecmuası'nın da "Moda" başlığı altında dönemin Batı modasını yansıtan kadınlara ait giysi önerilerini çeşitli sayılarında okuyucuları ile buluşturduğu görülmektedir.

Çalışmanın bu bölümünde 1909-1914 (1325-1330) yılları arasında Osmanlıca olarak yayımlanmış ve özellikle dönemin kentli Müslüman Türk kadınları tarafından büyük bir ilgi ile takip edilmiş olan Şehbâl Mecmuası'nda yer alan kadınlara ait giysi önerileri ele alınarak ortaya çıkarılmıştır. Her bir giysi önerisi, mecmua içerisinde yer alan ifadesiyle başlıklar altında sınıflandırılarak açıklanmıştır. Mevcut açıklamada Şehbâl Mecmuası'nda dönem kadınlarına hangi giysi modellerinin önerildiği görselleri ile birlikte ortaya konulmuş, böylece kadınların mevcut dönemde takip ettikleri giysi modası hakkında bir çıkarım yapılmak istenmiştir.

\subsubsection{Sokak ve Ev Tuvaletleri Mevsim Eșkâl-i Libası}

Mecmuanın 15 Mart 1914 (15 Mart 1330) tarihinde yayımlanan 93'üncü sayısı incelendiğinde, mevcut sayının 420'nci sayfasında yer alan "Sokak ve Ev Tuvaletleri Mevsim Eşkâl-i Libası” (Tuvalet: Fransızca kökenli "toillete" sözcüğünden dilimize geçmiş olan bu sözcük, dilimizde "kadınların gece toplantılarında giydikleri gösterişli giysi" anlamını karşılamaktadır (Tuvalet, t.y.), Eşkâl: Arapça kökenli "eşkâl" sözcüğünden dilimize geçmiş olan bu sözcük, dilimizde "biçimler, şekiller, kılık” anlamlarını karşılamaktadır (Eşkâl, t.y.), Libas: Arapça kökenli "libas" sözcüğünden dilimize geçmiş olan bu sözcük, dilimizde "giysi” anlamını karşılamaktadır (Libas, t.y.)) başlıklı, iki farklı giysi önerisinin kadın okuyucu kitlesi için sunulduğu görülmektedir (Resim 2).

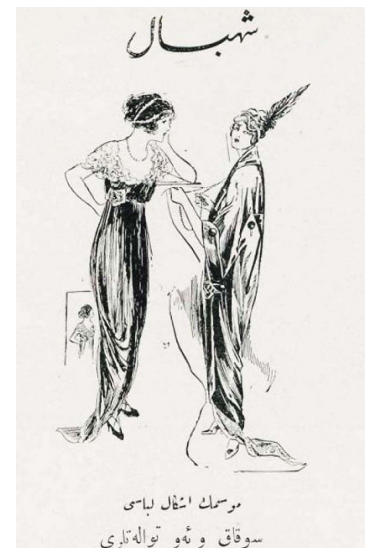

Resim 2. Sokak ve ev tuvaletleri mevsim eşkâl-i libası 
Ortaya konulan başlıktan da anlaşılabileceği gibi önerilen giysilerin hem açı hem de kapalı mekânlarda giyilebilecek mevsimsel davet giysileri olduğu ifade edilmiştir. Mevcut dönemin sahip olduğu Batı modasını doğrudan ortaya koyan bu giysi önerilerinin, sadece bir giysi önerisi olmadı ̆̆ 1 bununla birlikte mecmua içerisinde yer alan saç aksesuarları, ayakkabı örnekleri vb. betimlemelerle dönemin Batı kadınını doğrudan yansıttığı ile karşılaşılmaktadır. Osmanlı İmparatorluğu içerisinde yaşayan Müslüman Türk kadınlara sunulan bu giysi önerilerinin dönemde sıklıkla düzenlenen çay partileri, akşam yemekleri ve balo gibi davetlerde giyilmiş olabileceği düşünülmektedir.

\subsubsection{Kadın Libaslarının Yeni Eşkâlinden Sade Bir Kıyafet}

Mecmuanın 1 Nisan 1914 (1 Nisan 1330) tarihinde yayımlanan 94'üncü sayısı incelendiğinde, mevcut sayının 440’ıncı sayfasında yer alan "Kadın Libaslarının Yeni Eşkâlinden Sade Bir Kıyafet” başlıklı giysi önerisinin kadın okuyuculara sunulduğu ortaya çıkmaktadır (Resim 3).

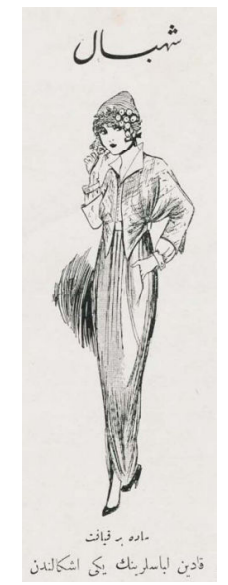

Resim 3. Kadın libaslarının yeni eşkâlinden sade bir kıyafet

Önerilen giysinin başlığından da anlaşılabileceği gibi giysinin dönem kadınları için yeni bir giysi modeli olduğu, bununla birlikte abartılı bir yapıda olmadığı ve günlük yaşamda kullanılabilecek bir öneriyi içerdiği görülmektedir. Osmanlı İmparatorluğu'nda yaşayan kadınlar için yeni bir tarzın temsilcisi olan bu giysi önerisinin gömlek, ceket ve etek gibi Batı tarzlı giyim-kuşam parçalarından oluştuğu ile karşılaşılmaktadır. Mevcut giysi önerisinin belirtilen dönemde monden olarak tanımlanan kadınlar tarafından dış mekân giysisi olarak giyilmiş olabileceği düşünülmektedir. Mecmua tarafından sunulan giysi önerisinde yer alan giysi parçaları ile birlikte, mevcut illüstrasyonda betimlenen kadının baş aksesuarı ve ayakkabı tarzlarıyla dönemin giysi modasını şekillendiren Paris modasını yansıttığı da ortaya çıkmaktadır.

\subsubsection{Yeni Libaslar Karşısında Bir Mevsim Kıyafeti}

Mecmuanın 15 Nisan 1914 (15 Nisan 1330) tarihinde yayımlanan 95'inci sayısı incelendiğinde, mevcut sayının 460'ıncı sayfasında yer alan "Yeni Libaslar Karşısında Bir Mevsim Kıyafeti” başlıklı giysi önerisinin kadın okuyuculara sunulduğu ortaya çıkmaktadır (Resim 4).

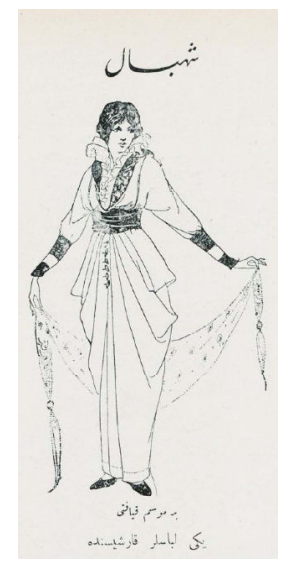

Resim 4. Yeni libaslar karşısında bir mevsim kıyafeti

Dönemin Batı tarzlı moda anlayışını ortaya koyan ve mecmua tarafından yeni giysiler karşısında mevsime yönelik bir giysi olduğu ifade edilen giysi önerisinin diğer giysi önerilerinde olduğu gibi Art Nouveau etkisini taşıdığı 
görülmektedir. Dönemin Osmanlı İmparatorluğu içerisinde yaşayan Müslüman Türk kadınlar için çok radikal bir öneri olan bu giyim-kuşam yapısının, mevcut döneme kadar kadınlarda pek de görülmeyen pantolon, bluz ve ceket gibi giysi parçalarından oluştuğu ile karşılaşılmaktadır. Giysi önerisinin yanı sıra giysi üzerinde yer alan süsleme detayları ve avangart (Frasızca kökenli "avant-garde" sözcüğünden dilimize geçmiş olan bu sözcük, dilimizde "öncü” anlamını karşılamaktadır (Avangart, t.y.)) yapısı ile bir davet giysisi olarak giyilmiş olabileceği düşünülmektedir.

\subsubsection{Silsile-i Melabis İçinden Muhtâsâr Bir İktibas İki Zarif Bluz}

Mecmuanın 1 Mayıs 1914 (1 Mayıs 1330) tarihinde yayımlanan 96'ncı sayısı incelendiğinde, mevcut sayının 480'inci sayfasında yer alan "Silsile-i Melabis İçinden Muhtâsâr Bir İktibas İki Zarif Bluz" (Silsile: Arapça kökenli "silsile" sözcüğünden dilimize geçmiş olan bu sözcük, dilimizde "birbirine bağll, birbiriyle ilgili șeylerin oluşturduğu dizi, sıra" anlamlarını karşılamaktadır (Silsile, t.y.), Melabis: Arapça kökenli “melabis" sözcüğünden dilimize geçmiş olan bu sözcük, dilimizde "giyecekler, elbiseler" anlamlarını karşılamaktadır (Develioğlu ve Kılıçkını, 1975), Muhtâsâr: Arapça kökenli "muhtaşar" sözcügünden dilimize geçmiş olan bu sözcük, dilimizde "kısaltılmış olan, kısa, özet" anlamlarını karşılamaktadır (Muhtâsâr, t.y.), İktibas: Arapça kökenli "iktibas" sözcüğünden dilimize geçmiş olan bu sözcük, dilimizde "ödünç alma" anlamını karşılamaktadır (İktibas, t.y.)) başlıklı iki farklı giysi önerisinin kadın okuyucu kitlesine sunulduğu görülmektedir (Resim 5).

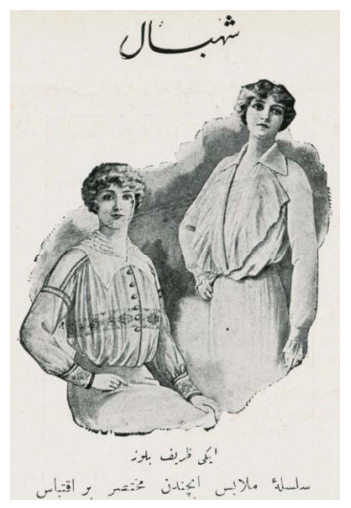

Resim 5. Silsile-i melabis içinden muhtâsâr bir iktibas iki zarif bluz

Ortaya konulan başlıktan da anlaşılabileceği gibi önerilen bu iki şık bluzun birbirleriyle benzerlik taşıyan giysiler içerisinden seçildiği ifade edilmiştir. Mevcut dönemde Osmanlı kadınlarına önerilen bu bluzların, bilek boyuna kadar uzanan etekler ile birlikte giyildikleri, bununla birlikte yaka ve kol detayları gibi göstergelerle dönemin Batı tarzını fazlasıyla yansıttığı ortaya çıkmaktadır. Ayrıca mecmua tarafından önerilen bu bluzların, kadınlar tarafindan günlük yaşam içerisinde hem iç hem de dış mekân giysisi olarak giyilmiş olabileceği düşünülmektedir.

\subsubsection{Ufk-ı Nisadan Eşkâl-i Melabise Nazar Rahat Bir Ev Libası}

Mecmuanın 15 Mayıs 1914 (15 Mayıs 1330) tarihinde yayımlanan 97'nci sayısı incelendiğinde, mevcut sayının 20'nci sayfasında yer alan "Ufk-1 Nisadan Eşkâl-i Melabise Nazar Rahat Bir Ev Libası" (Ufk: Arapça kökenli "ufk" sözcüğünden dilimize geçmiş olan bu sözcük, dilimizde "görünüș, çevre" anlamlarını karșılamaktadır (Ufk, t.y.), Nisa: Arapça kökenli "nisa" sözcüğünden dilimize geçmiş olan bu sözcük, dilimizde "kadınlar" anlamını karşılamaktadır (Develioğlu ve Kılıçkını, 1975), Nazar: Arapça kökenli "nazar" sözcüğünden dilimize geçmiş olan bu sözcük, dilimizde "bakış, bakma, göz atma" anlamlarını karşılamaktadır (Nazar, t.y.)) başıklı iki farklı giysi önerisinin kadın okuyucu kitlesine sunulduğu görülmektedir (Resim 6).

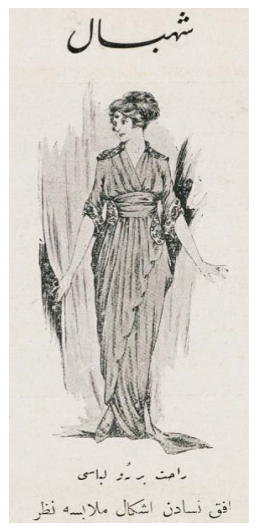

Resim 6. Ufk-1 nisadan eşkâl-i melabise nazar rahat bir ev libası 
Dönemin Batı tarzlı moda anlayışını ortaya koyan bu giysi önerisi, mecmua tarafından kadınların giysi görünümlerine bir bakış ev giysileri başlığıyla ifade edilmiştir. Bir gece kıyafeti görünümünde olan bu giysinin döneme ait kadınlar tarafından özel gün ve davetlerde iç mekân giysisi olarak giyilmiş olabileceği düşünülmektedir.

\subsubsection{Melabisin Seyr-i Serî’inden Bir Sayfa Bu Misafirlik Libası}

Mecmuanın 1 Haziran 1914 (1 Haziran 1330) tarihinde yayımlanan 98'inci sayısı incelendiğinde, mevcut sayının 40’ıncı sayfasında yer alan "Melabisin Seyr-i Serî’inden Bir Sayfa Bu Misafirlik Libası” (Seyr-i Serî: Arapça kökenli "seyr" ve "seri" sözcüklerinden dilimize geçmiş olan bu sözcük, dilimizde "sürekli bir şekilde hareket eden” anlamını karşılamaktadır (Seyr-i Serî, t.y.)) başlıklı iki farklı giysi önerisinin kadın okuyucu kitlesine sunulduğu görülmektedir (Resim 7).

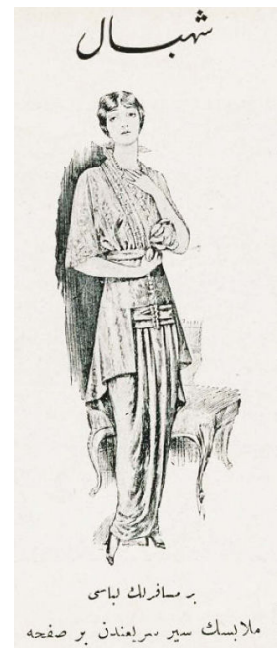

Resim 7. Melabisin seyr-i serî'inden bir sayfa bu misafirlik libası

Önerilen giysinin başlığından da anlaşılabileceği gibi mevcut dönemde kadınlar için çok fazla giysi önerisinin yapıldığ ve birden fazla sunulan giysiler arasından bu giysi önerisinin okuyucular için seçildiği ve okuyuculara sunulduğu görülmektedir. Ayrıca önerilen bu giysinin günlük yaşamda kullanılabilecek bir giysi olmadığı, bununla birlikte misafirlik giysisi olarak kadınlara tanıtıldığı ile karşılaşılmaktadır. Ortaya çıkan bu durum Osmanlı İmparatorluğu'nda yaşayan kadınların günün çeşitli zaman dilimlerinde ve mekânlarda birbirinden farklı giysilerin tercih edildiğinin göstergelerinden birisi olarak açıklanabilmektedir.

\subsubsection{Karadan Denize Moda ile Bu Senenin İlk Deniz Kostümü}

Mecmuanın 15 Haziran 1914 (15 Haziran 1330) tarihinde yayımlanan 99'uncu sayısı incelendiğinde, mevcut sayının 60'ıncı sayfasında yer alan “Karadan Denize Moda ile Bu Senenin İlk Deniz Kostümü” başlıklı iki farklı giysi önerisinin kadın okuyucu kitlesine sunulduğu görülmektedir (Resim 8).

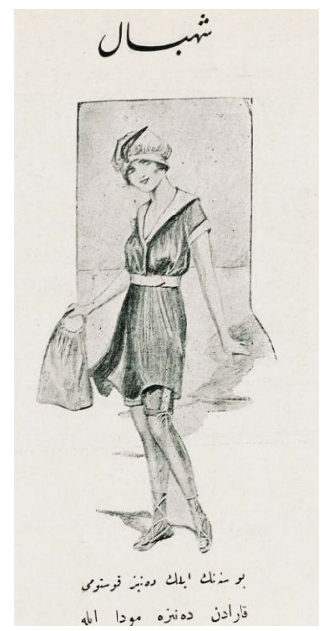

Resim 8. Karadan denize moda ile bu senenin ilk deniz kostümü

Önerilen giysinin başlığından da anlaşılabileceği gibi mevcut dönemde yaşayan kadınlar tarafından pek bilinmeyen ve kadınlar için çok yeni olan deniz modası kavramının belirmeye başladığı ile karşılaşılmaktadır. 
Özellikle mevcut dönemin şartları ve toplumsal yapısı göz önünde bulundurulduğunda, Batı toplumları için bile radikal bir giysi önerisi olan bu deniz giysisinin, Osmanlı İmparatorluğu içerisinde yaşayan Müslüman Türk kadınlar tarafından fazlasıyla radikal bir şekilde karşılandığı düşünülmektedir. Mecmua tarafından önerilen bu deniz kostümünün mevcut dönemden sonraki zaman diliminde oluşmaya başlayacak deniz modası için öncü bir giysi modeli olduğu ortaya çıkmaktadır.

\subsubsection{Melâhat Libasiye Eşkâlinden Bir Kıyafet-i Kâbul}

Mecmuanın 15 Temmuz 1914 (15 Temmuz 1330) tarihinde yayımlanan 100'üncü ve son sayısı incelendiğinde, mevcut sayının 80'inci sayfasında yer alan "Melahat Libasiye Eşkâlinden Bir Kıyafet-i Kâbul" (Melâhat: Arapça kökenli "melâhat" sözcüğünden dilimize geçmiş olan bu sözcükler, dilimizde "güzellik, şirinlik, sevimlilik" anlamlarını karşılamaktadır (Develioğlu ve Kılıçkını, 1975)) başlıklı iki farklı giysi önerisinin kadın okuyucu kitlesine sunulduğu görülmektedir (Resim 9).

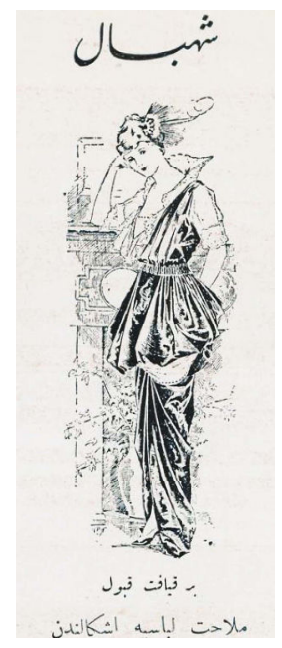

Resim 9. Melâhat libasiye eşkâlinden bir kıyafet-i kâbul

Dönemin Batı tarzlı moda anlayışını ortaya koyan bu giysi önerisinin, mecmua tarafından ifade edilen başlığından da anlaşılacağı gibi, güzel giysiler içerisinden bir kabul ya da diğer bir ifade ile davet giysisi olarak tanımlandığı ortaya çıkmaktadır. Mevcut giysi önerisi incelendiğinde, giysinin özel gün ve davetlerde giyilmiş olabileceği düşünülmektedir. Bununla birlikte önerilen bu giysinin dönemin Batı modasını tamamıyla yansıttığı da görülmektedir.

\section{Sonuc}

Osmanlı İmparatorluğu'nda II. Meşrutiyet Dönemi ile birlikte önemli bir şekilde artan Batılılaşma etkisi, sosyal alanın diğer kollarında olduğu gibi giyim-kuşam, aksesuar, saç ve makyaj gibi konuları kapsayan moda kavramını da oldukça etkilemiş̧tir. Bu etkileşim sonucunda eğitimli olan kentli Müslüman Türk kadınları, süreli yayınlarından birisi olan mecmualar sayesinde dönemin giyim-kuşam tarzını şekillendiren Paris modası hakkında bilgi sahibi olmuşlardır. Mevcut dönemde on beş günde bir yayımlanmıș Şehbâl Mecmuası sayılarında yer verdiği giysi önerileri ile kadınlara dönemin Batı modasını tanıttığı, böylece kadınların giyim-kuşam tarzlarını șekillendirdiği ve giysilerdeki değişime etki ettiği düşünülmektedir. Özellikle mecmuanın 1914 (1330) y1lına ait 93'üncü ve 100'üncü sayı aralığındaki yayınlarında dönemin Batı modasını yansıtan kadınlara ait giysi önerileri yer almıştır. "Sokak ve Ev Tuvaletleri Mevsim Eşkâl-i Libası", "Kadın Libaslarının Yeni Eşkâlinden Sade Bir Kıyafet", "Yeni Libaslar Karşısında Bir Mevsim Kıyafeti”, "Silsile-i Melabis İçinden Muhtâsâr Bir İktibas İki Zarif Bluz", "Ufk1 Nisadan Eşkâl-i Melabise Nazar Rahat Bir Ev Libası", "Melabisin Seyr-i Serî’inden Bir Sayfa Bu Misafirlik Libası", "Karadan Denize Moda ile Bu Senenin İlk Deniz Kostümü" ve "Melâhat Libasiye Eşkâlinden Bir Kıyafeti Kâbul" başlıkları ile mecmua içerisinde yer alan kadın giysi önerileri, mevcut dönemde giysi modasındaki Batılılaşma etkisini gözler önüne sermektedir. Mevcut giysi önerileri ele alındığında, belirtilen dönemde Osmanlı İmparatorluğu'nda yaşamış Müslüman Türk kadınları Şehbâl Mecmuası aracılığıyla ev giysileri, misafirlik giysileri, davet giysileri, deniz giysileri vb. adlarla tanımlanmış giysi önerileri ile tanışıı̧lardır. Mevcut dönemde dünyada öncü olan Paris modasından ilham alan kentli Müslüman Türk kadınları, takip ettikleri Batı tarzlı giyimkuşam özelliklerini mevcut giysileri ile bütünleștirmişlerdir. Ortaya çıkan bu durum özellikle Osmanlı kadınının giyim-kuşam tarzları ile yoğun bir Batılılaşma etkisi altında olduğunu da ortaya çıkarmıştır. Bununla birlikte, Osmanlı İmparatorluğu'nun yıkılmasından sonra yerini bırakacağı yeni kurulan Türkiye Cumhuriyeti'nin ilk dönemlerinde görülen Batı tarzlı kadın giysi modasının temellerinin özellikle II. Meșrutiyet Dönemiyle birlikte atıldığı düşünülmektedir. 


\section{Kaynakça}

Ahmetoğlu, S. (2010). Ittihatçı aktüaliteden kitlesel popülariteye: Şehbâl Mecmuası (1909-1914). İstanbul: Libra Kitapçılık ve Yayıncılık.

Avangart. (t.y.). Türk Dil Kurumu güncel Türkçe sözlük içinde. Erişim adresi: https://sozluk.gov.tr/

Barbarosoğlu, F. K. (2012). Modernleşme sürecinde moda ve zihniyet. İstanbul: İz Yayıncılık.

Çakır, S. (2011). Osmanlı kadın hareketi. İstanbul: Metis Yayınları.

Demir, M. (2016). Osmanlı kadınları arasında modanın yaygınlaşmasında bir araç olarak biçki-dikiş. Bartın Üniversitesi Edebiyat Fakültesi Dergisi, 1(2), 71-90.

Demir, M. (2018). Biçki dikiş. E. Gürsoy Naskali (Ed.), Osmanlı'dan Cumhuriyet'e faaliyet gösteren ilk dikiş kursu: Türk kadınları biçki yurdu (s. 57-124) içinde. İstanbul: Libra Kitapçılık ve Yayıncılık.

Demirdirek, A. (2011). Osmanlı kadınlarının hayat hakkı arayışının bir hikayesi. Ankara: Ayizi Kitap.

Denman, F. K. (2009). İkinci Meşrutiyet döneminde bir Jön Türk dergisi: Kadın. İstanbul: Libra Kitapçılık ve Yayıncilık.

Develioğlu, F., \& Kılıçkını, N. (1975). Osmanlıca-Türkçe okul sözlüğü (1. Baskı). İstanbul: Rafet Zaimler Kitabevi.

Eşkâl. (t.y.). Türk Dil Kurumu güncel Türkçe sözlük içinde. Erişim adresi: https://sozluk.gov.tr/

Himam, F. D., \& Tekcan, E. (2014). Erken Cumhuriyet Dönemi terzilik kültürü ve ulusal maddi kültürün inşası. Cumhuriyet Tarihi Araştırmaları Dergisi, Güz 2014 (20), 221-254.

İktibas. (t.y.). Türk Dil Kurumu güncel Türkçe sözlük içinde. Erişim adresi: https://sozluk.gov.tr/

Kocabaşoğlu, U. (2010). Hürriyeti beklerken İkinci Meşrutiyet basını. İstanbul: İstanbul Bilgi Üniversitesi Yayınları.

Libas. (t.y.). Türk Dil Kurumu güncel Türkçe sözlük içinde. Erişim adresi: https://sozluk.gov.tr/

Matris. (t.y.). Türk Dil Kurumu güncel Türkçe sözlük içinde. Erişim adresi: https://sozluk.gov.tr/

Melabis. (t.y.). Türk Dil Kurumu güncel Türkçe sözlük içinde. Erişim adresi: https://sozluk.gov.tr/

Monden. (t.y.). Türk Dil Kurumu güncel Türkçe sözlük içinde. Erişim adresi: https://sozluk.gov.tr/

Muhtâsâr. (t.y.). Türk Dil Kurumu güncel Türkçe sözlük içinde. Erişim adresi: https://sozluk.gov.tr/

Musavver. (t.y.). Türk Dil Kurumu güncel Türkçe sözlük içinde. Erişim adresi: https://sozluk.gov.tr/

Nazar. (t.y.). Türk Dil Kurumu güncel Türkçe sözlük içinde. Erişim adresi: https://sozluk.gov.tr/

Nisa. (t.y.). Türk Dil Kurumu güncel Türkçe sözlük içinde. Erişim adresi: https://sozluk.gov.tr/

Özer, İ. (2009). Osmanlı'dan Cumhuriyet'e yaşam ve moda. İstanbul: Truva Yayınları.

Risale. (t.y.). Türk Dil Kurumu güncel Türkçe sözlük içinde. Erişim adresi: https://sozluk.gov.tr/

Silsile. (t.y.). Türk Dil Kurumu güncel Türkçe sözlük içinde. Erişim adresi: https://sozluk.gov.tr/

Şahin, Y. (2015). Tarihin tekerini geriye döndürmek: Moda tasarımında geleneği yorumlama sorunsalı. Yedi: Sanat, Tasarım ve Bilim Dergisi, Kıș 2015 (13), 25-32.

Tefrika. (t.y.). Türk Dil Kurumu güncel Türkçe sözlük içinde. Erişim adresi: https://sozluk.gov.tr/

Toprak, Z. (2017). Türkiye'de yeni hayat inkllap ve travma 1908-1928. İstanbul: Doğan Kitap.

Tuvalet. (t.y.). Türk Dil Kurumu güncel Türkçe sözlük içinde. Erişim adresi: https://sozluk.gov.tr/

Ufk. (t.y.). Türk Dil Kurumu güncel Türkçe sözlük içinde. Erişim adresi: https://sozluk.gov.tr/

Uymaz, B. (2005). Şehbâl'de mûsikî yazıları (transkripsiyon ve yorum) (1.-50. sayılar) (Yüksek Lisans Tezi). YÖK tez veri tabanından erişildi (Tez No. 162322).

Uymaz, T. (2005). Şehbâl'de mûsikî yazıları (transkripsiyon ve yorum) (51.-100. sayılar) (Yüksek Lisans Tezi). YÖK tez veri tabanından erişildi (Tez No. 162571).

Y1lmaz, S. (2020). Giysiler ne anlatır?. İstanbul: Mundi Kitap. 


\section{Görsel Kaynakçası}

Resim 1. Bonn Üniversitesi Kütüphanesi Arşivi, (1910), Şehbâl Mecmuası kapak sayfasından bir örnek [İllustrasyon]. Erişim adresi: https://digitale-sammlungen.ulb.uni-bonn.de/3192015

Resim 2. Bonn Üniversitesi Kütüphanesi Arşivi, (1914), Sokak ve ev tuvaletleri mevsim eşkâl-i libası [İllustrasyon]. Erişim adresi: https://digitale-sammlungen.ulb.uni-bonn.de/3177223

Resim 3. Bonn Üniversitesi Kütüphanesi Arşivi, (1914), Kadın libaslarının yeni eşkâlinden sade bir kıyafet [İllustrasyon]. Erişim adresi: https://digitale-sammlungen.ulb.uni-bonn.de/3177185

Resim 4. Bonn Üniversitesi Kütüphanesi Arşivi, (1914), Yeni libaslar karşısında bir mevsim kıyafeti [İllustrasyon]. Erişim adresi: https://digitale-sammlungen.ulb.uni-bonn.de/3177161

Resim 5. Bonn Üniversitesi Kütüphanesi Arşivi, (1914), Silsile-i melabis içinden muhtâsâr bir iktibas iki zarif bluz [İllustrasyon]. Erişim adresi: https://digitale-sammlungen.ulb.uni-bonn.de/3177119

Resim 6. Bonn Üniversitesi Kütüphanesi Arşivi, (1914), Ufk-1 nisadan eşkâl-i melabise nazar rahat bir ev libası [İllustrasyon]. Erişim adresi: https://digitale-sammlungen.ulb.uni-bonn.de/3211334

Resim 7. Bonn Üniversitesi Kütüphanesi Arşivi, (1914), Melabisin seyr-i serî’inden bir sayfa bu misafirlik libası [İllustrasyon]. Erişim adresi: https://digitale-sammlungen.ulb.uni-bonn.de/3183337

Resim 8. Bonn Üniversitesi Kütüphanesi Arşivi, (1914), Karadan denize moda ile bu senenin ilk deniz kostümü [İllustrasyon]. Erişim adresi: https://digitale-sammlungen.ulb.uni-bonn.de/3183315

Resim 9. Bonn Üniversitesi Kütüphanesi Arşivi, (1914), Melâhat libasiye eşkâlinden bir kıyafet-i kâbul [İllustrasyon]. Erişim adresi: https://digitale-sammlungen.ulb.uni-bonn.de/3183303 